\title{
TEXTO FUNDAMENTAL
}

\section{PROSOPOGRAFIA ${ }^{1}$}

\author{
Lawrence Stone
}

\section{RESUMO}

O artigo faz uma apresentação geral da metodologia de pesquisa prosopográfica. Em primeiro lugar, faz-se uma revisão histórica dos primeiros esforços prosopográficos propriamente ditos, distinguindo as escolas elitista, de caráter mais individualizante, e a sociológica, de caráter mais coletivo. Na seqüencia, os precursores do método são apresentados, seguidos de alguns dos mais importantes trabalhos iniciais: as pesquisas historiográficas de Charles Beard e de Lewis Namier e a sociológica de Robert Merton. Em seguida, o autor comenta alguns dos principais problemas encontrados no uso acrítico da prosopografia: a ausência de dados adequados; erros nas classificações dos dados; erros nas interpretações dos dados; problemas na interpretação teórica dos dados. A identificação desses problemas não visa a negar a importância da prosopografia, mas a esclarecer quais os perigos que um uso descuidado dela podem acarretar; dessa forma, em seguida se apresentam alguns dos mais importantes resultados contemporâneos obtidos com a prosopografia, tomando como referência as pesquisas inglesas. Por fim, o autor comenta o quadro geral dos estudos prosopográficos contemporâneos, indicando sua situação nos Estados Unidos e na França, bem como as possibilidades e os perigos que a introdução do computador na prosopografia trazem para a prática historiográfica.

PALAVRAS-CHAVE: prosopografia; pesquisa histórica; Teoria Sociológica; teoria das elites; metodologia de pesquisa.

\section{ORIGENS ${ }^{2}$}

Nos últimos 40 anos, a biografia coletiva (segundo os historiadores modernos), a análise de carreiras (segundo os cientistas sociais) ou a prosopografia (segundo os antigos historiadores) desenvolveu-se como uma das mais valiosas e familiares técnicas do pesquisador histórico. A prosopografia $^{3}$ é a investigação das características comuns de um grupo de atores na história

\footnotetext{
${ }^{1}$ Este texto foi originalmente publicado na revista Doedalus (Cambridge, Mass., v. 100, n. 1, p. 46-79, Winter 1971), sob o título de "Prosopography". Tradução de Gustavo Biscaia de Lacerda e de Renato Monseff Perissinotto.

2 A pesquisa para este artigo foi apoiada pela bolsa GS 1559X da National Science Foundation.

3 A palavra "prosopografia" tem uma longa história: seu primeiro uso conhecido é de 1743 (NICOLET, 1970; estou em dívida para com os editores de Annales por uma consulta a esse artigo na fase de provas). Ela fornece um termo preciso e acurado para um método histórico cada vez mais comum e já é de uso corrente por um grupo na profissão. Parece, portanto, bastante desejável que se torne de uso cotidiano entre os modernos historiadores.
}

por meio de um estudo coletivo de suas vidas. O método empregado constitui-se em estabelecer um universo a ser estudado e então investigar um conjunto de questões uniformes - a respeito de nascimento e morte, casamento e família, origens sociais e posição econômica herdada, lugar de residência, educação, tamanho e origem da riqueza pessoal, ocupação, religião, experiência em cargos e assim por diante. Os vários tipos de informações sobre os indivíduos no universo são então justapostos, combinados e examinados em busca de variáveis significativas. Eles são testados com o objetivo de encontrar tanto correlações internas quanto correlações com outras formas de comportamento ou ação.

A prosopografia é usada como uma ferramenta com a qual se atacam dois dos mais básicos problemas na história. $\mathrm{O}$ primeiro refere-se às origens da ação política: o desvelamento dos interesses mais profundos que se considera residirem sob a retórica da política; a análise das afiliações sociais e econômicas dos agrupamentos políticos; a revelação do funcionamento de uma máquina política e a identificação daqueles que manipulam 
os controles. O segundo refere-se à estrutura e à mobilidade sociais: um conjunto de problemas envolve a análise do papel na sociedade, especialmente as mudanças nesse papel ao longo do tempo, de grupos de status específicos (usualmente da elite), possuidores de títulos, membros de associações profissionais, ocupantes de cargos, grupos ocupacionais ou classes econômicas; um outro conjunto de problemas refere-se à determinação do grau de mobilidade social em determinados níveis por meio de um estudo das origens familiares (sociais e geográficas), dos novatos [recruits] de um certo status político ou posição ocupacional, o significado dessa posição em uma carreira e o efeito de deter essa posição sobre as fortunas da família; um terceiro conjunto de problemas lida com a correlação de movimentos intelectuais ou religiosos com fatores sociais, geográficos, ocupacionais ou outros. Assim, aos olhos de seus expoentes, o propósito da prosopografia é dar sentido à ação política, ajudar a explicar a mudança ideológica ou cultural, identificar a realidade social e descrever e analisar com precisão a estrutura da sociedade e o grau e a natureza dos movimentos em seu interior. Inventada como um instrumento da história política, ela é agora crescentemente empregada pelos historiadores sociais.

Os maiores contribuidores para o desenvolvimento da prosopografia podem ser divididos em duas escolas razoavelmente distintas. Aqueles da escola elitista preocupam-se com a dinâmica de pequenos grupos ou com a interação, em termos de família, casamento e laços econômicos, de um número restrito de indivíduos. Os temas de estudo são usualmente as elites do poder, tais como os senadores da Roma antiga ou dos Estados Unidos ou os membros do parlamento inglês ou os membros dos gabinetes ingleses, mas os mesmos processos e modelos podem ser e são aplicados aos líderes revolucionários (LASSWELL \& LERNER, 1965). A técnica empregada consiste em fazer uma investigação meticulosamente detalhada sobre a genealogia, os interesses comerciais e as atividades políticas do grupo, os relacionamentos expostos por meio de detalhados estudos de caso, apoiados apenas de maneira secundária e em um grau relativamente menor por suportes estatísticos. O propósito de tal pesquisa é demonstrar a força de coesão do grupo em tela, mantido unido por laços sangüíneos, sociais, educacionais e econômicos, sem falar de preconcei- tos, ideais e ideologia. Quando o problema principal é político, argumenta-se que é essa rede de vínculos puramente sociais e econômicos que dão ao grupo sua unidade e, portanto, sua força política e, em grande medida, também sua motivação política, visto que a política é uma questão dos "de dentro" contra os "de fora". Esta escola deve pouco ou nada às Ciências Sociais, apesar de que poderia ter aprendido muito com elas, e é largamente inocente quanto ao uso consciente de teorias sociológicas ou psicológicas. Seus pressupostos, entretanto, entendem claramente a política mais como uma questão de interações entre pequenas elites dirigentes e seus clientes do que como movimentos de massa e esse auto-interesse, entendido como uma feroz competição hobbesiana pelo poder, pela riqueza e pela segurança, é o que faz o mundo girar (RUSTOW, 1966).

A segunda escola é mais estatisticamente orientada, voltada para o estudo das massas e inspira-se deliberadamente nas Ciências Sociais. Em sua maioria, os membros desta escola estão preocupados com todos (ou alguns) aqueles sobre os quais nada muito detalhado ou íntimo pode ser conhecido, pois estão mortos e, portanto, indisponíveis para entrevistas. Os membros desta escola têm uma concepção de que a história é determinada mais pelos movimentos da opinião popular do que pelas decisões dos assim chamados "grandes homens" ou pelas elites; eles têm consciência de que não há utilidade em definir as necessidades humanas apenas em termos de poder e de riqueza. Eles são necessariamente mais preocupados com a história social que com a política $\mathrm{e}$, portanto, procuram investigar um rol mais amplo, ainda que inevitavelmente mais superficial, de questões que aquelas usualmente pesquisadas pelos membros da escola elitista. Eles também são bem mais preocupados com os testes das correlações estatísticas das diversas variáveis que em dar a conhecer um sentido da realidade histórica por meio de uma série de detalhados estudos de caso. Desse modo, como eles tentam descrever o passado, eles tendem a fazê-lo mais por meio da construção de tipos ideais weberianos que pela apresentação de uma série de exemplos concretos. Muito de seu trabalho refere-se à mobilidade social, mas alguns olham para relações estatisticamente significativas entre o ambiente e as idéias e entre as idéias e o comportamento político ou religioso. As duas escolas, assim, diferem signifi- 
cativamente em seus objetos de estudo e um pouco em seus pressupostos, meios e objetivos, mas elas são similares em seu interesse comum no grupo, mais que no indivíduo ou na instituição.

Tanto a escola elitista quanto a de massas tornaram-se primeiramente identificáveis na profissão durante as décadas de 1920 e 1930, quando vários trabalhos apareceram e tiveram um profundo efeito em todo o desenvolvimento posterior. As matérias-primas com as quais esses estudos prosopográficos foram e são elaborados são principalmente de três grandes tipos: listas simples de nomes de ocupantes de certos cargos ou títulos ou qualificações profissionais ou educacionais; genealogias de famílias; dicionários biográficos inteiros, que são usualmente elaborados em parte com base nas duas primeiras categorias e em parte com base em uma variedade de fontes infinitamente mais ampla. O recolhimento de materiais biográficos desse tipo progrediu bastante antes que os primeiros "prosopógrafos" profissionais aparecessem em cena. Para tomar o caso da história inglesa (embora a história romana pudesse igualmente ser um bom exemplo (NICOLET, 1970)), ao longo do período que vai do final do século XVIII ao início do século XX, antiquários, clérigos e acadêmicos diligentes produziram informação biográfica de todos os tipos em quantidades bastante impressionantes. Das editoras públicas e privadas fluiu um rio de coleções biográficas de cada descrição e de cada qualidade: membros do parlamento, pares, baronetes, pequena nobreza [gentry], arcebispos de Canterbury, clero londrinense, chanceleres, juízes, serjeants-at$l a w^{4}$, oficiais militares, recusantes católicos ${ }^{5}$, refugiados huguenotes, professores de Oxford e Cambridge - a lista é quase infinita (COLLINS, 1714; 1720; CAMPBELL, 1742-1744; CHARNOCK, 1794-1798; WILSON, 1806; BURKE, 1833-1838; CAMPBELL, 1845-1847;

\footnotetext{
4 Os sarjeants-at-law eram advogados responsáveis com exclusividade pela tramitação de alguns processos; há relatos a seu respeito anteriores ao século XIV, mas com o reinado de Elizabeth I (1558-1603) eles passaram a perder influência e importância, até serem extintos no início do século XX (nota dos tradutores).

5 Os recusantes católicos eram os católicos que, como o nome indica, recusavam-se a cumprir os ritos anglicanos na Inglaterra, sujeitando-se, é claro, a penalidades variadas. As leis que os apenavam valeram do século XVI ao século XIX, com variadas intensidades (N. T.).
}

1849; HOOK, 1860-1876; MUNK, 1861; WOOLRYCH, 1869; FOSS, 1870; GILLOW, 1885-1902; AGNEW, 1886; FOSTER, 1891-1892; DALTON, 1892-1904; 1910; HENNESSY, 1898; BEAVEN, 1908-1913; VENN \& VENN, 19221954).

O propósito dessa abundância - que se realizou nos Estados Unidos, na Alemanha e em outros lugares - não é de todo claro, pois a prosopografia como um método histórico não fora inventada e essas publicações não eram usadas por historiadores profissionais, exceto como minas de onde se poderia extrair blocos de informações a respeito de indivíduos particulares. Em termos de motivações psicológicas, esses colecionadores obsessivos de informações biográficas pertencem à mesma categoria dos machos erótico-anais como os colecionadores de borboletas, de selos postais ou de carteiras de cigarros; todos são subprodutos da ética protestante. Mas parte do estímulo veio do orgulho ou da afeição local ou institucional, que assumiu a forma de um desejo de recordar os membros passados de uma corporação, de uma faculdade, de uma profissão ou de uma seita. Parte também derivou de uma paixão inexaurível pela genealogia e pela caçada de ancestrais que dominou grandes parcelas das classes altas inglesas desde o século XVI. Com a grande expansão da classe média educada no século XIX e com o crescimento das bibliotecas universitárias e públicas, havia afinal um mercado suficientemente grande para justificar a publicação desses volumes que eram, na verdade, esotéricos e ilegíveis.

A suprema aquisição desse movimento inglês secular para a biografia coletiva foi a realização do grande Dictionary of National Biography [Dicionário da biografia nacional], que é um monumento permanente à motivação e à dedicação dos vitorianos na busca de informações sobre os indivíduos mortos. Quando os primeiros praticantes da prosopografia histórica passaram a trabalhar após a I Guerra Mundial, eles portanto encontraram à disposição uma massa de informações biográficas já coletada e impressa, apenas esperando ser analisada, coletada e usada para construir uma figura inteligível da sociedade e da política.

O primeiro historiador a adotar o método elitista da prosopografia a fim de tratar de um grande problema histórico foi Charles Beard, que já em 1913 ofereceu uma explicação para o estabeleci- 
mento da constituição federal estadunidense a partir de uma análise cerrada dos interesses econômicos e classistas dos Founding Fathers (BEARD, 1913). No capítulo-chave - "Os interesses econômicos dos membros da Convenção" -, ele perguntou a si mesmo se eles representavam "grupos distintos cujos interesses econômicos compreendiam e sentiam de maneiras concretas e definidas em suas próprias experiências pessoais com idênticos direitos de propriedade ou se trabalhavam somente sob a orientação de princípios abstratos de Ciência Política". Sua conclusão era inequívoca: "Os primeiros passos firmes rumo à formação da Constituição foram tomados por um pequeno e ativo grupo de homens imediatamente interessados, em função de suas posses, no resultado de seus trabalhos", uma conclusão obtida por meio de uma biografia econômica de todos aqueles conectados a esse processo. Esse memorável e brilhante trabalho pioneiro parece curiosamente ter tido pouca influência nos desenvolvimentos posteriores à I Guerra, talvez devido ao quadro dogmaticamente rígido de determinismo econômico no qual ele foi construído. No seu prefácio de 1935, Beard tentou negar que essa sua atitude em relação ao determinismo econômico fosse aplicável a tudo, que ele fora profundamente influenciado pelo pensamento marxista ou que ele estivesse atribuindo motivos sórdidos ou autointeressados aos Founding Fathers. Contudo, suas negativas não eram totalmente convincentes (BEARD, 1935, p. 73, 324, xii-xiv). A contribuição de Beard para a prosopografia elitista foi uma curiosidade suspeita a respeito das finanças de um ator político e a hipótese de que elas eram importantes. O que lhe escapou foi o papel dos vínculos sociais e de parentesco que seriam tão importante nos estudos posteriores de Sir Lewis Namier e outros. Por outro lado, a obra de Beard deve ter sido familiar a Namier, que, por maior que tenha sido sua repulsa pelo determinismo econômico marxista, certamente deve ter-se impressionado com o poder interpretativo do método.

Um ano depois, um outro pesquisador estadunidense, A. P. Newton, publicou um livro menos conhecido que levou o método um pouco adiante (NEWTON, 1914). Ele cuidadosamente traçou as relações de parentesco e as conexões econômicas de modo a demonstrar a formação da liderança puritana oposicionista a Carlos I na década de 1630 . Seu livro foi claramente um modesto predecessor do de Namier, mas por alguma razão, talvez devido ao seu título um tanto proibitivo, ele nunca atraiu muita atenção geral ${ }^{6}$.

A verdadeira marca no sentido da aceitação geral pela profissão não ocorreu senão quando da publicação dos livros de Namier, Structure of Politics at the Accession of George III (London, 1929), de Sir Ronald Syme, Roman Revolution (Oxford, 1939), e de R. K. Merton, "Science, Technology, and Puritanism in Seventeenth Century England" (Osiris, v. IV, 1938, p. 360632). Todos os três estavam aptos a abordar o estoque de informações biográficas que foram acumuladas e publicadas ao longo dos séculos anteriores. Merton usou o Dictionary of National Biography para seu trabalho, Syme estava em débito com dois historiadores alemães - M. Gelzer e F. Münzer - e Namier pôde explorar 130 anos de organização de dados a respeito da vida dos $\mathrm{M}$. P.s. O trabalho pioneiro da escola alemã de prosopografia anterior à I Guerra foi de considerável importância para o posterior desenvolvimento da prosopografia clássica - e possivelmente também da moderna -, mas suas realizações foram ofuscadas pelos trabalhos mais impressionantes e ambiciosos de Namier e de Syme. Distantes de Beard e de Newton, os últimos dois foram os primeiros historiadores de notável capacidade a usar esse tipo de abordagem para tentar uma reinterpretação maior de um desenvolvimento político crítico que já fora estudado ad nauseam por historiadores mais convencionais por um período bastante longo. Ambos trabalharam de maneira impressionística por meio de estudos de caso e de anedotas pessoais, que eles usaram para elaborar um quadro dos interesses pessoais da elite, principalmente os agrupamentos de parentesco, as afiliações comerciais e uma complicada rede de favores concedidos e recebidos.

O terceiro estudo, de R. K. Merton, era bem diferente tanto em seus objetivos quanto em seu método. De modo mais apropriado para um sociólogo estadunidense que para um historiador britânico, o que ele produziu foi uma biografia de grupo baseada em estatísticas, mais que um retrato de grupo composto a partir de uma série de estudos de caso. O problema que ele propuserase também era diferente, pois não tentava estudar ações políticas específicas, mas um estado de

6 Ele não teve seguimento até a publicação do livro de Hexter (1941). 
espírito e explicava um conjunto mental não por meio de vínculos familiares ou de interesses econômicos, mas de afiliações ideológicas: ele tentava vincular uma atitude favorável à ciência natural à fidelidade ao que ele frouxamente descrevia como puritanismo. Por outro lado, seu trabalho era similar ao de Namier e de Syme no que ele examinava - embora com uma profundidade de pesquisa muito menor -, isto é, o comportamento de uma elite mais que o da massa.

Tanto Syme quanto Namier, mas particularmente este último, tiveram uma enorme influência sobre a geração seguinte de pesquisadores em seus campos de especialidade. Alguns anos atrás um resenhista examinou os trabalhos recentes e correntes dos historiadores da política britânica do século XVII e, dos problemas que se propuseram e dos métodos que utilizaram para solucionálos, concluiu que eram todos membros de uma única corporação: "Namier Ltda." (RAYMOND, 1957, p. 499-500). Hoje ambos os métodos, o de estudos de caso e o estatístico - e especialmente o último -, difundiram-se para outros períodos e áreas e são aplicados em uma crescente escala a cada aspecto do processo histórico, a cada tempo e a cada lugar. A escola das massas agora tem um próspero sub-ramo chamado psefologia, ou análise do comportamento do eleitorado; a escola elitista produziu um sub-ramo mais científico, a análise dos nomeados para cada legislatura. Essas duas novas áreas específicas estão absorvendo crescentes quantidades de tempo, dinheiro e atenção dos historiadores e dos cientistas políticos 7 .

\section{RAÍZES INTELECTUAIS}

Que esses desenvolvimentos ocorreram no mesmo período em escritos de pesquisadores trabalhando de maneira inteiramente independente (Sir Ronald Syme assegura-me que não lera Namier) prova que há mais neles que mera descoberta casual. A prosopografia não teria florescido da maneira como floresceu nos anos 1920 e 1930 se não tivesse ocorrido uma crise na profissão historiográfica, que já era discernível para os jovens mais perceptivos da geração seguinte ${ }^{8}$. Essa crise vicejou a partir da quase exaustão da grande tradição acadêmica de historiografia ocidental,

7 Alguns exemplos foram publicados em Rowney e Graham (1969, parte VI).

8 Os líderes dessa revolução intelectual foram os franceses Marc Bloch e Lucien Febvre. estabelecida no século XIX. Baseada em um estudo cerrado dos arquivos estatais, suas glórias foram as histórias institucional, administrativa, constitucional e diplomática. Mas os maiores avanços nessas áreas foram todos feitos pela raça de gigantes dos finais das eras vitoriana e eduardiana, sendo as figuras extraordinárias da história inglesa C. W. Stubbs, T. F. Tout, F. W. Maitland e S. R. Gardiner. Em suas buscas de novos e mais frutíferos caminhos para entender o funcionamento das instituições, alguns jovens historiadores logo antes e depois da I Guerra Mundial começaram a passar da análise cerrada de textos de teoria política e de documentos constitucionais ou da elucidação da maquinaria burocrática para um exame dos indivíduos envolvidos e das experiências a que eles estavam sujeitos. Exasperado com a devoção oca de uma geração de intérpretes históricos da composição da constituição estadunidense, Beard redigiu a "Introdução" de seu próprio livro com o ácido comentário segundo o qual "a constituição teve uma origem humana imediatamente, pelo menos - e ela agora é discutida e aplicada por seres humanos que se encontram engajados em certas vocações, ocupações, profissões e certos interesses". Em sua desafiadora afirmação introdutória de um quarto de século depois, Syme também declarou guerra aberta à geração anterior de historiadores (BEARD, 1913, p. xiv; SYME, 1939, p. vii) ${ }^{9}$. Quando lidou com as atitudes do parlamento a respeito das colônias estadunidenses antes da Revolução Americana, Namier não se incomodou com a teoria política da taxação sem representação; ao invés disso, ele perguntou: "Que conhecimento das colônias estadunidenses tinha a Casa em que a Lei do Selo foi aprovada e revogada e na qual as Leis de Townshend foram decretadas? Quantos de seus membros foram às colônias americanas, tinham vínculos com eles ou tinham um conhecimento íntimo dos assuntos americanos? Algum deles era nascido na América?"10 (NAMIER, 1961, p. 229).

9 Para uma descrição dessa drástica mudança historiográfica, cf. Nicolet (1970).

10 Alguns esclarecimentos históricos necessários: Lei do Selo (Stamp Act): lei aprovada em 1765 pelo parlamento britânico e que exigia que quaisquer impressos nas colônias britânicas na América deveriam utilizar papel produzido na Inglaterra e certificado com um selo; essa lei foi aprovada sem a participação de representantes dos colonos e 
Seguindo esse exemplo, questões semelhantes sobre "quem", mais que sobre "o quê", foram formuladas a respeito de questões tão diversas na historiografia inglesa como a Magna Carta, a Câmara dos Comuns, rebeliões, o funcionalismo público e os gabinetes ministeriais (NEALE, 1949; KEELER, 1954; AYLMER, 1961; HOLT, 1961; GUTTSMAN, 1963; NAMIER \& BROOKE, 1964; HOBSBAWM \& RUDE, 1969). A premissa implícita é que uma compreensão de quem os atores foram levará mais longe a explicação do funcionamento da instituição a que eles pertenceram, revelará os verdadeiros objetivos atrás do fluxo de retórica política e tornar-nos-á mais capazes para entender suas realizações, assim como para interpretar mais corretamente os documentos que produziram.

A direção em que esse ataque à abordagem convencional das instituições políticas e das políticas públicas desenvolver-se-ia foi poderosamente influenciada por outras importantes tendências no clima intelectual do período, das quais a primeira e mais importante era o relativismo cultural. Maior familiaridade com países estrangeiros por meio de viagens combinada com o crescente volume de estudos antropológicos revelaram o extraordinário leque de padrões culturais que são adotados por diferentes sociedades ao redor do globo. $\mathrm{O}$ público instruído tornou-se incomodamente consciente de que a moral, o Direito, as constituições, as crenças religiosas, as atitudes políticas, as estruturas de classe e as práticas sexuais diferem amplamente de uma sociedade para outra; essa consciência a seu tempo levou ao reconhecimento de que há poucas normas universais para o comportamento humano ou para a organização social. A ênfase no condicionamento ambiental como o fator determinante na criação dessa vari-

motivou uma grande reação política, na América e na Inglaterra, contribuindo para criar o clima que resultou, dez anos depois, na independência dos Estados Unidos; em 1766 essa lei foi revogada.

As leis de Townshend (Townshend Acts ou, como Lawrence Stone usa, Townshend Duties) foram um conjunto de leis propostas pelo Ministro das Finanças britânico em 1767, Charles Townshend, e aprovadas pelo parlamento, visando a, entre outras coisas, tributar os colonos americanos com vistas ao pagamento dos governantes locais, punir o estado de Nova Iorque e impor tributos sem representação dos colonos. É quase desnecessário dizer que essas leis produziram revoltas e conflitos e que, assim, foram elementos importantes na Revolução Americana (N. T.). edade era a maior possível, pois os anos 1920 e 1930 foram períodos em que as explicações genéticas das diferenças culturais não foram tratadas com a seriedade que agora começava a parecer que possivelmente mereceriam ${ }^{11}$. O darwinismo social, que fora uma poderosa influência pela virada do século, dava maior ênfase na criação que na natureza. Além disso, os psicólogos freudianos, que logo após começaram a desenvolver suas próprias abordagens, também conferiram grande ênfase na infância e na experiência sexual inicial. Deve-se admitir, todavia, que a psicologia freudiana não tem muita utilidade para o historiador, que usualmente é inábil para penetrar nos quartos, nos banheiros ou nos berçários. Se Freud está correto e se são esses os lugares em que a ação encontra-se, não há muito que o historiador possa fazer. A modificação subseqüente das idéias freudianas, realizada por Erik Erikson, de acordo com quem a formação do caráter continua ao longo da infância e da adolescência e cristaliza-se em uma "crise de identidade" logo antes da maturidade, oferece novas possibilidades para o historiador, que pode às vezes descobrir um pouco sobre os pensamentos e os sentimentos de seu objeto de pesquisa em sua adolescência, mesmo que se conheça pouco ou nada de sua meninice e de sua primeira infância. Até o momento, todavia, a psicologia de Erikson tem sido bem pouco usada pelos historiadores e uma influência muito mais importante sobre a profissão têm sido as teorias comportamentalistas de desafios e respostas às pressões ambientais.

O terceiro elemento de influência no clima intelectual do período foi a redução da confiança na integridade dos políticos e o declínio da crença na importância das constituições. Muito desse cinismo foi gerado pelo desastre político e moral da I Guerra Mundial, seguido pelo colapso das esperanças em uma ordem mundial melhor. Muitas pessoas passaram a acreditar que essa era a época em que milhões morreram e a civilização européia desintegrara-se, enquanto os políticos manobravam uns aos outros por cargos e poder, procurando exceder-se mutuamente na retórica chauvinista do ódio. O resultado foi a penetração nos círculos intelectuais e nas classes superiores

11 Para uma pesquisa sugestiva, ainda que altamente especulativa, sobre as possibilidades da influência da genética, cf. Darlington (1969). 
do antigo folclore dos pobres, segundo o qual todos os políticos são canalhas. Essa foi a era do exibicionismo, em que o topo social desvinculouse do século XIX, com livros como Eminent Victorians (1918), de Lytton Strachey, e The Robber Barons (1934), de Mathew Josephon. Também não se deve esquecer que os eventos do período não fizeram nada para corrigir a balança; foi a época de Teapot Dome, Jimmy Thomas e Stavisky ${ }^{12}$. Essas suposições populares e descobertas reais a respeito da permissividade moral e sobretudo financeira dos políticos levaram os historiadores a pensar que motivos similares só poderiam ser revelados como força motriz da história se fosse possível ter acesso aos documentos particulares dos atores políticos do passado.

À parte o fascismo (que tinha pouco apelo intelectual), o marxismo era a única ideologia poderosa do período. $\mathrm{O}$ marxismo concedeu a vários historiadores uma crença um tanto ingênua no determinismo econômico, que reforçou fortemente essas suspeitas sombrias sobre as motivações humanas. Beard então declarou que "o principal motivo orientador" por trás dos elaboradores da constituição estadunidense "eram as vantagens econômicas que os beneficiários esperavam obter para si próprios" (BEARD, 1913, p. 17-18). Nesses estágios iniciais, portanto, a prosopografia refletia uma atitude profundamente pessimista em relação aos comportamentos humanos e era conduzida tanto pelos radicais sob a influência marxista, como Beard, quanto por homens como Sir Lewis Namier e Sir Ronald Syme, que eram ostensivamente conservadores em suas formas de pensar. Syme franca-

12 O Teapot Dome foi um escândalo político estadunidense ocorrido em 1922 e 1923, em que membros do governo do Presidente Warren Harding receberam propinas para o licenciamento da exploração de reservas de petróleo.

Jimmy Thomas foi um ferroviário e líder sindical inglês que, sendo eleito deputado, participou de diversos gabinetes na Inglaterra na primeira metade do século XX. Em meados dos anos 1930, foi acusado de vazar segredos financeiros públicos para banqueiros e especuladores, o que resultou no fim da sua carreira pública.

O caso Stavisky tratou-se de desvio de recursos públicos na França, ocorrido em 1934. O fraudador Alexandre Stavisky aplicava diversos golpes; em 1934 ele fraudou a cidade de Bayonne, vendendo títulos seguro falsos; para isso, foi apoiado por diversas autoridades, em que, mesmo que de maneira inocente, chegava-se até a Presidência da República (N. T.). mente admitia a respeito de seu próprio trabalho que "O desenho de pesquisa impôs uma tonalidade pessimista e truculenta às custas da quase completa exclusão das emoções cavalheirescas e das virtudes domésticas", enquanto um resenhista de primeira hora comentou com assombro que no livro de Namier "O sistema político que ele descreve certamente não é atrativo, baseado como era em um auto-interesse possivelmente esclarecido, mas certamente sórdido" (WINSTANLEY, 1929, p. 660; SYME, 1939, p. viii).

Esse cinismo também não se limitava às atitudes face a políticos individuais, mas também se dirigia aos sistemas políticos. Se as revoluções significam nada mais que a substituição de uma elite governante coesa e autocentrada por outra, se um punhado de homens inescrupulosos pilotam o barco do Estado da maneira como querem, qualquer que seja a bandeira constitucional sob a qual eles viajam, então a diferença entre a tirania e a democracia torna-se obscura, para dizer o mínimo. Desse ponto de vista, a escola elitista de historiadores prosopógrafos dos anos 1930 era profundamente afetada pela crise contemporânea de confiança na democracia. Namier deliberadamente pretendeu destruir teorias a respeito de uma conspiração tirânica de Jorge III contra a constituição britânica e Syme pretendeu remover qualquer base para julgamentos morais sobre a destruição da república romana por Augusto. Em 1939 A. Momigliano aplicou a Syme sua própria descrição de Tácito: "um monarquista do desespero perspicaz da natureza humana" (MOMIGLIANO, 1940, p. 5). Robert Dahl corretamente observou, todavia, que "para indivíduos com um forte traço de idealismo frustrado, ela [a teoria das elites] tem justamente o componente certo de rígido cinismo" (Dahl apud RUSTOW, 1966, p. 713). O teórico das elites e o historiador das elites tendem a desapontar os igualitários, pois sua misantropia surge diretamente de sentimentos morais ofendidos.

A atitude em relação ao funcionamento da política assumida pelos prosopógrafos iniciais parece dever pouco aos escritos de teóricos políticos. O próprio Marx enfatizou primeiro o papel dos senhores feudais e depois o da burguesia e dirigiu sua atenção para o auto-interesse que guiou suas ações. Mas as primeiras teorias políticas completamente elitistas provieram da Europa no início do século XX, com os escritos de R. Michels, G. 
Mosca e V. Pareto. Embora Michels estivesse disponível em francês, Pareto e Mosca não foram traduzidos para o inglês antes dos anos 1930 e não há nenhuma evidência de que eles tenham tido a menor influência nos círculos historiográficos do mundo anglo-saxão antes dessa época. Namier, Merton e Syme eram fortemente antimarxistas e ainda assim somente Merton parece ter tido familiaridade com esses modelos elitistas antimarxistas. $\mathrm{O}$ que temos, assim, é o desenvolvimento pelos teóricos políticos de uma teoria completa do governo das elites uma geração antes de os historiadores porem-se a trabalhar. Mas com exceção de Merton, os historiadores levaram a cabo suas pesquisas empíricas baseados em seus pressupostos semiconscientes a respeito do comportamento político, sem o benefício da teoria política que lhes teria fornecido a estrutura de que necessitavam. Esse é um dos episódios mais estranhos da história intelectual, uma conseqüência da lerdeza com que os grandes cientistas sociais europeus são traduzidos para o inglês e do isolamento da história em relação às outras Ciências Sociais no início do século XX.

Um aspecto-chave da interpretação elitista do processo histórico é a remoção deliberada e sistemática tanto dos programas partidários quanto das paixões ideológicas do centro do palco político e sua substituição por uma complexa rede unindo os patrões a seus clientes e dependentes. Para a história romana, isso é expressamente afirmado pelos professores L. R. Taylor e E. Badian (TAYLOR, 1949, p. 23; BADIAN, 1958, p. 1). Para a história inglesa, Namier substituiu a "conexão" pelo partido como o princípio organizador central da política de meados do século XVIII, K. B. McFarlane inventou a expressão "feudalismo bastardo" para representar relações semelhantes entre patrões e clientes que ele acreditava poderiam explicar o século XV, enquanto Sir John Neale tomou emprestada a palavra "clientela" ["clientage"] dos historiadores clássicos para dar sentido ao sistema político elizabetano. Em uma passagem-chave, o último autor escreveu: "muitos da pequena nobreza parecem ter-se agrupado em relações estreitas ou fracas ao redor de um ou outro dos poucos grandes homens do interior [...]. $\mathrm{O}$ agrupamento e a interdependência da pequena nobreza, com sua acompanhante, a constante luta por prestígio e supremacia, permeava a vida inglesa. Eles supõem que o papel desempenhado pela política em nossa sociedade moderna, e no interi- or, é a principal pista para as eleições parlamentares" (MCFARLANE, 1945; NEALE, 1949, p. 4 , 27). Para alguns pesquisadores, a prosopografia não é meramente uma forma de ignorar as paixões e as idéias; ela foi adotada com o propósito específico de neutralizar esses elementos perturbadores e intratáveis.

Um quarto estímulo para a prosopografia elitista, que por seu turno reforçou a nova consciência do essencial papel desempenhado na política pelas associações de dependentes, foi a quase obsessiva preocupação dos antropólogos com a família e o parentesco, cujo impacto total está apenas começando a fazer-se sentir completamente na profissão de historiador atualmente. Foi o trabalho de Namier sobre a política inglesa de meados do século XVIII que primeiramente orientou a atenção dos historiadores para as potencialidades dos arranjos familiares e dos vínculos de parentesco como elos políticos (NAMIER, 1961, p. 19; cf. também SYME, 1939, p. vii; NEALE, 1949; ANNAN, 1955; HOLT, 1961). Talvez não seja tão improvável ver um paralelo entre a preocupação com tais vínculos da escola elitista de historiadores e preocupações similares na ficção contemporânea, notavelmente em $\grave{A}$ la recherche du temps perdu de Proust e o mais recente Music of Time, de Antony Powell.

Essas tendências intelectuais são suficientes em si mesmas para explicar a ascensão da escola elitista entre as guerras. A escola das massas, orientada de maneira mais científica, obviamente deve algo a todas essas tendências, mas muito mais à ascensão concorrente das Ciências Sociais. De Weber a Merton os mais inteligentes e os mais bem-sucedidos dos cientistas sociais limitaramse a avançar hipóteses de nível médio a respeito de coisas como o suicídio, ou a burocracia, ou a receptividade a perspectivas políticas de direita. A prosopografia histórica obviamente é de imenso valor como uma fonte de materiais para tais investigações e não é coincidência que Marx, Weber e Merton tenham todos tido fortes interesses históricos. A principal inspiração para o tipo de questões formuladas e para os métodos empregados para solucioná-las por Merton e uma multidão de investigadores históricos subseqüentes da escola de massas foi o desenvolvimento de técnicas de survey sociais. Delas provêm a confiança no método de amostragem e o hábito de formular um conjunto bastante amplo de questões, muitas das 
quais acabam revelando-se completamente irrelevantes, na esperança de distinguir as variáveis significativas pela manipulação estatística posterior.

Dadas essas várias tendências convergentes da vida intelectual no período compreendido entre as duas guerras mundiais, é dificilmente surpreendente que tenha sido então que a prosopografia floresceu. De fato, em retrospecto o que é surpreendente é a lentidão de seu avanço na cena histórica, pois foi somente nos anos 1950 , ou mesmo nos anos 1960, que um número significativo de pesquisadores começou a usar o método e que um fluxo regular de achados úteis começou a ser publicado.

\section{LIMITES E PERIGOS}

Experiência suficiente acumulou-se agora para tornar possível avaliar tanto as potencialidades quanto as limitações das pesquisas prosopográficas. Alguns dos erros e das deficiências são conseqüências inevitáveis do pioneirismo em um método novo e podem ser evitados no futuro pelo aprendizado com os erros do passado. Outros, todavia, são mais profundos e surgem de alguns pressupostos políticos e psicológicos que estão incorporados nas fundações da prosopografia.

\section{III.1. Deficiências dos dados}

É auto-evidente que as pesquisas biográficas de números substanciais de pessoas somente são possíveis para grupos razoavelmente bem-documentados e que a prosopografia é assim limitada pela quantidade e pela qualidade dos dados acumulados sobre o passado. Em qualquer grupo histórico, é provável que quase tudo será sabido a respeito de alguns de seus membros e quase nada a respeito de outros; alguns itens faltarão para alguns e itens diferentes faltarão para outros. Se o montante de coisas desconhecidas é muito grande e se junto com as seriamente incompletas formam uma substancial maioria do todo, as generalizações baseadas nas médias estatísticas tornarse-ão de fato bastante frágeis, quando não totalmente impossíveis. Pesquisas que têm que se limitar à décima ou à vigésima parte do grupo a cujo respeito sabe-se o suficiente dependem para sua fidedignidade que a minoria conhecida seja uma amostra genuinamente aleatória do todo. Mas essa é uma suposição improvável, pois o mero fato de que mais que o usual foi registrado a res- peito das vidas e das carreiras de uma pequena minoria indica que elas eram de alguma forma atípicas. Em um grau que não pode ser medido, pesquisas baseadas em tais evidências fragmentárias tenderão a exagerar, e talvez de maneira incorrigível a distorcer, o status, a educação, a mobilidade vertical e assim por diante a respeito do grupo sob exame. Para muitos grupos, em muitas áreas, a prosopografia não pode ser utilmente empregada antes da explosão de registros do século XVI, causada pela invenção da imprensa móvel, pela difusão da alfabetização e o crescimento do Estado-nação burocrático e arquivístico.

A única exceção a essa generalização é quando existe uma única pesquisa de tipo censitário, como a catasto florentina de 1427. Esses documentos raros permitem cortes transversais [cross section] em uma sociedade em um determinado momento, mas eles não podem responder nenhuma pergunta a respeito da mudança ao longo do tempo, pois usualmente não há nada antes ou depois com os quais os comparar. Eles também necessitam ser manuseados com cuidado, pois podem silenciosamente omitir certas classes de pessoas, como os mendigos; suas categorias podem ser vagas ou erráticas e suas estatísticas financeiras provavelmente subestimam a afluência dos ricos em relação aos pobres.

A segunda limitação imposta pela evidência registrada refere-se ao status. Em todos os lugares e épocas, quanto mais baixo vai-se no sistema social, mais pobres ficam os documentos. Como resultado, muitas pesquisas que já foram feitas ou que estão sendo realizadas devotaram-se às elites. $\mathrm{O}$ objeto mais popular para a prosopografia foram e ainda são as elites políticas, mas outros grupos que se prestam mais facilmente a tal tratamento são membros de certas categorias de alto status, como funcionários públicos, oficiais da Marinha, o alto clero, intelectuais e educadores, advogados, médicos [doctors], membros de outros corpos profissionais e empresários industriais e comerciais. Os únicos elementos das classes baixas a respeito de quem alguma coisa pode ser feita que não seja altamente impressionista são as minorias perseguidas, pois os relatórios policiais e legais com freqüência oferecem muito da informação necessária, especialmente em sociedades com longas tradições de pesado controle burocrático e policial, como a França. O estranho resultado é que os únicos grupos de pobres e humildes a respeito de quem às vezes podemos des- 
cobrir bastante são as minorias, que por definição são excepcionais, pois estão em revolta contra os hábitos e as crenças da maioria.

A terceira limitação imposta pelas evidências surge do fato de que elas são abundantes para alguns aspectos da vida humana e quase inexistentes para outros. Os registros sobreviventes referem-se antes de mais nada ao montante, ao tipo, à titularidade e à transmissão da propriedade. É essa a primeira preocupação dos registros legais oficiais e privados, de impostos públicos e das administrações públicas e privadas, que em conjunto formam a vasta massa do material escrito do passado. Assim, há um forte viés nos sentidos de tratar os indivíduos como homo oconomicus e de estudá-los primariamente à luz de seus interesses e comportamentos financeiros, pois é isso que os registros iluminam com enormes claridade e detalhe. Mas os interesses econômicos podem entrar em conflito e, mesmo quando o interesse é claro, é impossível estar-se seguro de que ele é a consideração dominante. Além disso, a divisão entre aqueles que aceitam compromissos e aqueles que adotam medidas extremas é com freqüência mais importante politicamente que a divisão entre grupos de interesses econômicos claramente definidos (cf., por exemplo, AYDELOTTE, 1967; 1969).

Após os interesses econômicos, o segundo item de informações que são relativamente fáceis de descobrir a respeito de alguém são suas origens e ligações familiares. Entre as classes superiores, o casamento foi usado no passado para fornecer aos homens jovens amigos e contatos úteis, bem como para absorver propriedades e assim criar grandes patrimônios territoriais. Os laços familiares também desempenharam um importante papel na construção de grupos e partidos políticos em todos os momentos da Idade Média ao século XVIII e além. Deve-se apenas pensar nos Howards e nos Dudley na Inglaterra do século XVI, nos Villiers no início do século XVII, nos Pelhams no século XVIII e nos Cecils e nos Cavendishes no final do século XIX e no início do século XX para reconhecer a contínua importância desse fator. Mas isso não responde a questão de quão longe é seguro prosseguir nessa linha de raciocínio, pois a ação de cimento do parentesco claramente varia de lugar para lugar, de período para período e de nível social para nível social. Há incontáveis exemplos na história de membros da mesma família que discordaram en- tre si, com freqüência com extrema violência. Além disso, mesmo quando os laços de parentesco eram fortes e pode-se demonstrar que o eram, há limites para a busca significativa de vínculos genealógicos. Dois prosopógrafos diligentes pesquisando sobre o Longo Parlamento de 1640 traçaram conexões genealógicas que relacionavam o radical John Hampden ${ }^{13}$ a 80 companheiros membros do parlamento, mas infelizmente se verificou que esses parentes eram de opiniões políticas e religiosas enormemente variadas. Quando os autores descobriram que, voltando no tempo o suficiente, podiam encontrar uma conexão de parentesco entre Carlos I e Oliver Cromwel1 ${ }^{14}$, perceberam que talvez tivessem ultrapassado os limites da utilidade dessa linha específica de investigação. Dúvidas similares foram recentemente expressas a respeito do papel atribuído pela escola prosopográfica ao parentesco na Roma clássica (BRUNTON \& PENNINGTON, 1954) ${ }^{15}$.

\section{III.2. Erros na classificação dos dados}

Classificações significativas são essenciais para o sucesso de qualquer pesquisa, mas infelizmente para o historiador cada indivíduo desempenha muitos papéis, alguns dos quais estão em conflito com outros. Ele pertence a uma civilização, a uma cultura nacional e a uma multidão de subculturas - étnica, profissional, religiosa, amizades [peergroup], políticos, sociais, ocupacionais, econômicos, sexuais e assim por diante. Como resultado, nenhuma classificação é de validade universal e uma perfeita congruência das classificações é bem rara. Categorias de status podem guardar pouca relação com a riqueza e também podem

13 John Hampden (1595-1643) foi um político britânico, considerado um dos principais líderes da Revolução Inglesa (1640-1660), em particular como defensor das prerrogativas do parlamento e contra os esforços absolutistas da monarquia inglesa (N. T.).

14 Carlos I e Oliver Cromwell foram líderes políticos britânicos que estiveram em lados opostos na Revolução Inglesa; enquanto Carlos I era católico e a favor do absolutismo, Cromwell era protestante e a favor do parlamento. O significativo da oposição apresentada por Lawrence Stone é que Cromwell foi o responsável pela execução de Carlos I em 1649 , tendo assumido o poder em seguida e até sua morte, em 1658 (N. T.)

15 Para uma refutação convincente da teoria de "que os vínculos genealógicos e políticos normalmente coincidiriam" no início do século XVIII, cf. Meier (1966), Holmes (1967, p. 327-334) e Brunt (1968). 
variar em sua importância ao longo do tempo. Categorias de classes baseadas na riqueza podem não refletir as realidades sociais, podem ser quase impossíveis de identificar e podem ser mais difíceis de comparar ao longo do tempo; categorias profissionais podem atravessar as linhas tanto de status quanto de classe e subir e descer o sistema social; categorias de poder, bem como cargos políticos, podem variar ao longo do tempo em termos do status social vinculado a eles, do poder que possuem e da renda que obtêm.

O segundo perigo que ameaça cada prosopógrafo é que ele pode falhar em identificar subdivisões importantes e pode assim tratar conjuntamente indivíduos que diferem significativamente um do outro ${ }^{16}$. Uma boa pesquisa depende de um constante comércio entre as hipóteses e as evidências, as primeiras sofrendo repetidas modificações à luz das últimas. Mas se uma subdivisão que depois se revela de importância crítica não for notada a tempo, usualmente é tarde demais para voltar e realizar todo o trabalho de novo uma dificuldade que é particularmente aguda em pesquisas auxiliadas por computadores, pois os códigos determinam as questões que podem ser depois formuladas (TIRAT, 1963, p. 217).

\section{III.3. Erros na interpretação dos dados}

Mesmo se sua documentação é adequada e seu sistema de classificação é corretamente elaborado, o prosopógrafo imprudente está sujeito a tirar conclusões errôneas de seus dados. Um risco comum que se lhe apresenta é a possibilidade de que a porção da população total a respeito de quem ele pode descobrir informações confiáveis não representa uma amostra aleatória do total. Se o desconhecido geralmente cai em uma simples categoria enviesada, as figuras obtidas da amostra do conhecido darão uma imagem distorcida da realidade. Desse modo, o próprio Theodore Rabb oferece motivos para pensar que sua amostra dos investidores ingleses do século XVII é enviesada, pois muito provavelmente muitos dos seus $38 \%$ de investidores não identificados, tanto nomea-

16 Para um exemplo que foi criticado nesses termos, cf. Stone (1965a); cf. também Coleman (1966), Hexter (1968), Petersen (1968) e Woolf (1969). O fracasso em elaborar subcategorias suficientemente detalhadas reduziu seriamente a utilidade do estudo de Brunton e Pennington sobre o Longo Parlamento. dos quanto não nomeados, eram pequenos mercadores (RABB, 1967) ${ }^{17}$. Esse é um problema que afeta todos os trabalhos que usam essa metodologia e contra o qual as únicas defesas são a mais cuidadosa avaliação das probabilidades e a aplicação, onde necessário, de índices de erros para corrigir as estatísticas. Outro erro que com freqüência ocorre nas pesquisas prosopográficas origina-se de uma falha em relacionar os achados sobre a composição da população sob estudo com a da população em geral. Um bom exemplo das dificuldades em que o historiador pode tropeçar se ele negligencia esse aspecto é a disputa sobre a composição social das vítimas do Terror na Revolução Francesa. O Professor D. Greer descobriu que a grande maioria das vítimas eram originárias das classes inferiores ou médias, mais que da nobreza. Notou-se então que a proporção de nobres vítimas pode ter sido bastante pequena, mas como a proporção de nobres na população em geral era ainda menor, ainda há uma correlação entre o nascimento nobre e a execução. Podese ainda dizer que um nobre tinha $x$ vezes mais chances de ser morto no Terror que um membro da burguesia ou um camponês (GREER, 1964, p. $385-387)^{18}$.

Um outro tipo de erro que surge da negligência das relações entre a parte e o todo origina-se da suposição de que porque a maioria de membros de um certo grupo provém de uma classe social ou de uma ocupação particular, então eles são representativos, no sentido de que a maioria de membros dessa classe ou ocupação pertence ao grupo. Hugh R. Trevor-Roper indicou que os homens que tomaram o poder na Inglaterra no final dos anos 1640 e no início dos anos 1650 eram em sua maioria originários não da velha elite

17 Para uma resenha que indica esse e outros aspectos, cf. McCusker (1969). Um outro exemplo desse problema é a pretensão de David Pottinger de que os escritores do Antigo Regime francês eram originários predominantemente da noblesse d'épée [nobreza de espada] e da alta burguesia uma conclusão obtida após a eliminação de $8,5 \%$ de todos os escritores em virtude do fato de que sua origem social não poderia ser descoberta (cf. POTTINGER, 1958). Eu devo essa crítica ao Professor Robert Darnton.

18 Um exemplo um pouco diferente da mesma falácia é a tentativa de D. Lerner de mostrar que os líderes nazistas eram "homens marginais", quando sua definição de marginalidade claramente compreende mais da metade da população (RUSTOW, 1966, p. 702). 
fundiária, que governou a Inglaterra antes da guerra, mas da pequena nobreza pobre [poor gentry], da mere gentry ou da parish gentry ${ }^{19}$, que até então não tomara parte significativa nos negócios nacionais e somente um papel menor nos assuntos locais. Inspirado por essa descoberta, ele continuou e generalizou que a simples pequena nobreza socialmente decadente compunha os principais elementos insatisfeitos no interior e os principais apoiadores do radicalismo. De fato, todavia, parece agora razoavelmente claro que um número maior da mere gentry - na verdade, a maioria da classe no interior no Norte e no Oeste - eram homens leais à Igreja e ao Rei, que lutaram pelo rei Carlos. A pequena nobreza independente que apoiou Cromwell era apenas uma minoria atípica, instigada a tomar posição muito em desacordo com a maioria de sua classe por motivos que ora podemos apenas muito vagamente determinar, mas um dos quais era certamente a convicção religiosa (HOSKINS, 1952; TREVORROPER, 1953; EVERITT, 1966, p. 143-144, 243244; CLIFFE, 1969, cap. 15) ${ }^{20}$.

\section{III.4. Limitações da compreensão histórica}

Até aqui, os erros descobertos foram todos erros que podem ser evitados por meio do aprendizado com as duras lições da experiência, mas há outros que são mais difíceis de erradicar. Em primeiro lugar, a concentração no estudo das eli-

19 A respeito da tradução das expressões mere gentry e parish gentry (bem como outras semelhantes), seguimos a orientação dos professores Eunice Ostrenski e Modesto Florenzano, da Universidade de São Paulo (USP), para quem, devido às grandes dificuldades para traduzir a palavra "gentry", deve-se evitar traduzi-la. De acordo com eles, há uma imensa discussão entre os historiadores a respeito do significado desse termo (dos quais participam TrevorHoper, Clarke, Tawney etc.), de modo que adotar uma tradução específica é tomar partido - o que não vem ao caso na presente tradução. De qualquer forma, convém notar que gentry é o coletivo de gentlemen ("cavalheiros"). Por outro lado, mere gentry, middling gentry, parish gentry, pseudogentry etc. foram termos criados por Hugh TrevorHoper, que viu marcadas distâncias entre a gentry comum e a gentry mais empobrecida, sem cargos na corte e em declínio. Nesse caso, seria possível traduzir mere gentry e parish gentry respectivamente como "nobreza comum" e "nobreza paroquial". Agradecemos imensamente a Eunice Ostrenski e a Modesto Florenzano por esses esclarecimentos (N. T.).

20 Para um outro exemplo do mesmo erro, cf. Donald (1956) e Skotheim (1959). tes é em parte causa e em parte efeito de uma tendência a ver a história exclusivamente em termos da classe governante, em que os movimentos populares desempenham um pequeno ou nenhum papel. Syme afirmou que "Em todas as épocas, qualquer que fosse a forma e o nome do governo, fosse ele monarquia, república ou democracia, uma oligarquia permanece atrás da fachada" (SYME, 1939, p. 7). Isso é uma grande verdade tão longe aonde se vá, mas pode-se razoavelmente perguntar se isso vai longe o suficiente. Estudos cerrados das manobras políticas das elites podem obscurecer mais que iluminar as profundezas do funcionamento dos processos sociais. Grandes mudanças nas relações de classe, na mobilidade social, nas opiniões religiosas e nas atitudes morais podem estar ocorrendo nos estratos inferiores, as quais a elite será afinal obrigada a responder - isso caso não seja varrida por uma revolução violenta ${ }^{21}$.

Se olharmos os três mais brilhantes exemplos da pesquisa prosopográfica sobre as elites políticas publicadas nos anos 1950-Roman Revolution, de Syme, Structure of Politics, de Namier, e a grande trilogia da Câmara dos Comuns elizabetana de Sir John Neale -, poderemos ver o mesmo estreitamento de foco. Syme interpretou as transformações da república romana em um império como a consolidação de uma nova elite ao redor de Augusto, o resultado de uma complexa disputa facciosa no topo. Ele provou seu argumento, mas ignorou as urgentes demandas das massas de clientes anônimos para seus patrões e que apoiaram - e talvez impuseram - essa mudança de poder. Movimentos políticos, e revoluções ou contra-revoluções em particular, só com dificuldade podem ser satisfatoriamente explicados pelo estudo exclusivo da liderança. A descrição que Namier fez das manobras e das negociações na Câmara dos Comuns do século XVIII comprometeu irreparavelmente as teorias convencionais, mas seu modelo explicativo não pode incluir o surgimento do sentimento popular gerado por John Wilkes ou a Guerra da Independência dos Estados Unidos. De maneira semelhante, a descrição de Sir John Neale das relações entre a Rainha Elizabeth e seus parlamentos necessita de modificação por meio de uma apreciação mais acurada das raízes profundas que o puritanismo estava fin-

21 Cf. as observações de P. A. Brunt (1968, p. 230-231). 
cando na sociedade. Essa era uma ideologia que tanto permeava quanto explorava o nexo do clientelismo aristocrático que Sir John tão brilhante e convincentemente descreveu.

A segunda grande fraqueza intelectual dos prosopógrafos tem sido sua relativa relutância em inserir em sua perspectiva de história um papel para as idéias, os preconceitos, as paixões, as ideologias, os ideais ou os princípios. A correspondência pessoal íntima é uma raridade entre os registros históricos. Ela usualmente é destruída durante a vida ou na morte, pois, ao contrário dos registros genealógicos, legais ou comerciais, ninguém entre os familiares ou amigos tem qualquer incentivo para preservá-la. Mesmo nos raros casos em que esse material existe, com freqüência não é muito esclarecedor, pois os homens raramente confiam suas mais profundas convicções ao papel, mesmo com seus amigos. Além do mais, como em vários períodos da história foi positivamente perigoso expressar visões minoritárias sobre a religião ou a política, tais comentários escritos, como sobrevivência de temas básicos, tendem a restringir-se às normas aceitas da sociedade. $\mathrm{O}$ viés sistemático no registro histórico em favor dos interesses materiais e dos vínculos de parentesco e contrário a idéias e princípios adequou-se bem com a pressuposição explicitamente defendida pelos maiores dos primeiros membros da escola das elites (cf. BEARD, 1935, p. 13; NAMIER, 1961, p. 18). "Os interesses espirituais do povo são considerados muito menos que seus casamentos", reclamou Momigliano tão logo o livro de Syme apareceu. Sir Herbert Butterfield protestou, referindo-se a Namier, dizendo que "os seres humanos são os portadores de idéias, assim como os repositórios de interesses [vested interests $^{22}$ ]" (MOMIGLIANO, 1940, p. 6; BUTTERFIELD, 1957, p. 211).

A despeito de algumas retratações posteriores, há pouca dúvida de que na prática tanto Namier quando Syme concediam pouca importância a quaisquer ideais ou preconceito que contrariassem os cálculos do auto-interesse. A atenção dis-

22 "Vested interests" é uma expressão que usualmente descreve direitos de propriedade legalmente reconhecidos ou grupos que agem no sistema político para defender seus interesses. Como ela é de difícil tradução para o português, deixamos somente como "interesses" (N. T.) pensada por esses historiadores às táticas da política, mais que às suas estratégias, pressupõe uma sociedade sem convicções na qual a manipulação e as intrigas são mais importantes que questões de princípio ou de políticas públicas. Acontece que os meados do século XVIII, sobre o qual Namier centrou primeiramente sua atenção, foi um dos poucos períodos da história inglesa destituído de grandes temas controversos e um período em que os atores políticos constituíram um grupo excepcionalmente homogêneo: ele então escolheu, por acidente ou de propósito, um período e uma classe que eram especialmente suscetíveis de análise por meio dos métodos que ele adotou. Mas alguns de seus seguidores descobriram, às próprias custas, que nem sempre é seguro levar os mesmos pressupostos para frente e para trás no tempo. Robert Walcott tentou usar o modelo para o reinado da Rainha Ana, com resultados que são agora geralmente reconhecidos como estando bem próximos de desastrosos (WALCOTT, 1956; HOLMES, 1967, p. 2-4, 327-334; PLUMB, 1967, p. xiv, 44-46, 135-138). Pode-se também imaginar se o fracasso de Oliver Cromwell em lidar com sucesso com seus parlamentos realmente pode ser explicado por sua falta de habilidades táticas, como o Professor Trevor-Roper argumenta, ou se a discordância a respeito de temas constitucionais e religiosos fundamentais entre os militares e os civis e entre os independentes, os presbiterianos e os anglicanos inviabilizou a obtenção de um acordo mesmo para o mais perspicaz e assíduo manipulador de homens (TREVORROPER, 1967). Pode-se portanto concluir que o poder explicativo da teoria política de grupos de interesse, que tendeu a ser associada à abordagem prosopográfica elitista, é muito maior em alguns períodos e em alguns lugares que em outros. Quanto menor a presença de grandes temas políticos, mais baixa a temperatura ideológica, mais oligárquica a organização política, mais provável a formulação de uma interpretação histórica convincente.

Outra limitação da escola prosopográfica de historiadores é que seus membros às vezes negligenciam indevidamente a natureza da política, a moldura institucional dentro da qual o sistema funciona e a narrativa de como os atores políticos modelam as políticas públicas. "É-nos dada uma história que se inicia silenciosa ou curiosamente negligente assim que ela toca as próprias coisas que o governo e o parlamento existem para fa- 
zer", reclamou Sir Herbert Butterfield. Ele concluiu asperamente que "Há pouco interesse no trabalho dos ministros em seus departamentos; no nascimento de uma política pública e nas origens de decisões importantes; no conteúdo real de controvérsias políticas do momento; na atitude do público perante medidas e homens e nos golpes e contragolpes do debate parlamentar [...]. Tais tendências são calculadas para levantar a questão sobre se a nova forma de análise estrutural não é capaz de produzir nos praticantes da arte seu próprio tipo de doença ocupacional" (BUTTERFIELD, 1957, p. 208-209). A doença de que Sir Herbert reclama é uma forma de daltonismo que impede suas vítimas de perceberem o conteúdo político da política.

Muitos prosopógrafos elitistas instintivamente optam por uma visão simplista da motivação humana, de acordo com a qual as origens da ação são uma coisa ou outra. Todos nós exigimos de nossos alunos que distingam os motivos religiosos dos políticos nas políticas externas de Gustavo Adolfo, ou de Oliver Cromwell, ou de quem quer que seja. Na vida real, a natureza humana não parece funcionar dessa maneira. $\mathrm{O}$ indivíduo é movido pela convergência de forças em constante alteração, um aglomerado de influências como o parentesco, a amizade, os interesses econômicos, os preconceitos de classe, os princípios políticos, a convicção religiosa e assim por diante, todas as quais desempenham seus papéis e que podem ser utilmente separadas apenas com fins analíticos. Além disso, há razões para pensar-se que a importância relativa das várias características de fundo variarão de cultura para cultura, de nação para nação e de época para época; que algumas atitudes podem ser mais estreitamente relacionadas a atributos sociais que outras; que alguns atributos sociais são moderadamente influentes em relação a um grande espectro de atitudes enquanto outros são altamente influentes em relação a uma única atitude (EDINGER \& SEARING, 1967).

De qualquer forma, é essencial distinguir com nitidez entre temas relativamente menores, a respeito dos quais um político está suficientemente disposto a favorecer um parente ou um cliente ou a receber um suborno, e questões maiores, de princípio, a respeito das quais ele provavelmente seguirá os ditames de sua cabeça e de seu coração, mais que os de seu sangue ou de seu bolso.

\section{REALIZAÇÕES}

Nada do que foi dito até agora deve ser interpretado como se a prosopografia elitista fosse inútil ou enganosa por natureza. Bandeiras vermelhas foram hasteadas ao redor dos principais pontos de perigo onde ficaram os ossos de muitos pioneiros do método e procurou-se explicar porque se deveria reduzir as pretensões da prosopografia geralmente como uma ferramente exploratória. Se os erros passados podem ser evitados e se as limitações do método são reconhecidas, as potencialidades são muito grandes. De fato, pressupondo-se que se aceita - como seguramente deve ser - que os valores e os padrões de comportamento são influenciados poderosamente pela experiência passada e pela educação, o poder do método dificilmente pode ser negado. Tudo que é necessário é maior disposição para reconhecer a inconstante complexidade da natureza humana, o poder das idéias e a influência persistente das estruturas institucionais. A prosopografia não tem todas as respostas, mas ela é idealmente adequada para revelar as redes de vínculos sociopsicológicos que mantêm um grupo unido. Por exemplo, identificar tais laços entre os líderes da oposição parlamentar a Carlos I no final dos anos 1630 e no início dos anos 1640 não nos ajuda decidir se questões econômicas, constitucionais ou religiosas causaram a Guerra Civil. Mas certamente ilumina muito poderosamente o processo da formação do partido radical, ao fim, torna redundante qualquer questão semelhante, pela simples razão de que os homens não arrancam suas instituições políticas pela raiz exceto se todas essas influências estiverem operando em conjunto para formar um incentivo avassalador para a mudança.

A melhor forma para ilustrar todo o espectro das contribuições que a prosopografia tem feito para a compreensão histórica nos últimos 20 anos é focar em alguns lugares e épocas particulares, para o que a história religiosa, social e política da Inglaterra entre 1500 e 1660 servirá tão bem quanto qualquer outra. $\mathrm{O}$ primeiro grande problema que foi enormemente enriquecido por essas pesquisas é a Reforma inglesa. Embora durante as décadas de 1950 e 1960 o livro-texto dominante interpretasse esse evento em termos primariamente políticos, como um ato do Estado levado a cabo por um punhado de homens do topo, havia ao mesmo tempo em movimento toda uma série de 
monografias que refutaram esse quadro simples. Exames das condições educacional, moral e financeira do clero pré-Reforma demonstraram suas muitas fraquezas, mas também indicaram que o que estava acontecendo não era tanto um declínio da qualidade e do zelo do clero quanto um aumento das demandas feitas sobre ele pelos leigos (BOWKER, 1968; HEATH, 1969, p. 187-196). Vista sob essa luz, a Reforma torna-se também uma outra "revolução de expectativas crescentes". Os monges também foram estudados de maneira prosopográfica, com resultados similares, e estabeleceu-se que havia um declínio em números no período pré-Reforma e uma maciça fuga voluntária da reclusão monástica no início dos anos 1530. Monastérios e conventos podiam ser vistos tentando desesperadamente se adaptar às necessidades das classes superiores laicas funcionando como asilos de idosos para serviçais pensionistas, como hotéis para cavalheiros transeuntes e para nobres e como instituições para a guarda de crianças indesejadas (HODGETT, 1962). O destino dos monges após a Dissolução ${ }^{23} \operatorname{logo}$ foi sujeito à análise prosopográfica, que suprimiu as dúvidas acerca da falácia da velha lenda dos sofrimentos dos despossuídos (BASKERVILLE, 1937; HODGETT, 1962). O comportamento dos bispos durante a crise da Reforma foi elucidado e as divisões de opiniões, convincentemente relacionadas a diferentes formações acadêmicas - em Teologia ou em Direito - e a diferentes carreiras na Igreja ou na burocracia estatal (SMITH, 1953).

Ainda mais importante em suas conseqüências históricas que essas valiosas pesquisas sobre membros das hierarquias oficiais da Igreja foi a descoberta das origens do radicalismo religioso na sociedade secular. $\mathrm{O}$ grande avanço aqui veio com a publicação do trabalho pioneiro do Professor A. G. Dickens, Lollards and Protestants in the Diocese of York (1959), que usou fontes até então inexploradas e propôs todo um conjunto de novos problemas, que desde então tem sido aprofundado por pesquisadores e discípulos. Graças ao paciente rastreamento dos hereges protestantes nos registros de tribunais seculares e religiosos, o tamanho, a influência, a composição social, as características ocupacionais e a dispersão

23 A Dissolução refere-se ao processo de dissolução dos mosteiros realizada entre 1538 e 1541, por Henrique VIII, com a subseqüente absorção dos bens e das propriedades eclesiásticas pelo rei (N. T.). geográfica desses grupos minoritários perseguidos começaram afinal a sair das sombras. Nenhum pesquisador sério desconsidera mais a sobrevivência do lolardismo ${ }^{24}$ como sendo sem conseqüência na difusão das idéias religiosas radicais e podemos agora ver que a disseminação das idéias protestantes não meramente por meio das atividades de um punhado de acadêmicos em Cambridge, mas também por meio da penetração de panfletos luteranos importados, de Bíblias traduzidas e outras literaturas subversivas que iam das cidades portuárias para as áreas interioranas via comerciantes, tecelões, frades dissidentes e assim por diante (ASTON, 1964; CLEBSCH, 1964; DAVIS, 1966).

A história religiosa subseqüente da Inglaterra também se beneficiou enormemente da prosopografia. Demonstrou-se que os exilado marianos, que fugiram para o exterior a fim de escapar da perseguição católica entre 1553 e $1558^{25}$, eram uma elite social e intelectual para quem dificilmente há qualquer paralelo antes da migração de judeus da Alemanha hitlerista nos anos 1930; seu papel na determinação do formato do Ato Anglicano de 1558-155926 agora é reconhecido como tendo sido de grande importância (GARRETT, 1938; NEALE, 1953, parte I; WALZER, 1965, p. 92-113). Nossa compreensão de por que a Igreja Anglicana falhou em seus anos iniciais para ganhar maior aceitação e para conseguir mais conversões foi iluminada por meio da prosopografia clerical, que revelou deficiências em números, educação, zelo e independência econô-

24 O lolardismo, ou, em inglês, lollardy, consiste no seguimento das idéias de John Wyclif (1320-1384), teólogo de Oxford considerado um dos precursores da Reforma Protestante. O lolardismo vigeu entre os séculos XIV e XVI e, rejeitando a autoridade do Vaticano, pregava maior fidelidade à letra da Bíblia (N. T.).

25 O período em questão consiste no reinado de Maria I, chamada também de Maria a Sanguinária ("Blood Mary"), devido às perseguições feitas aos protestantes (N. T.).

26 O Ato Anglicano (Anglican Settlement) foi uma decisão proposta pela Rainha Elizabeth e promulgada pelo parlamento britânico que reinstituiu o anglicanismo como religião oficial do Estado inglês, com o rei (ou rainha, no caso) como líder espiritual supremo, além de questões teológicas e litúrgicas mais específicas. O objetivo dessa decisão foi pôr um termo à disputa religiosa que então agitava a Inglaterra, opondo em particular o anglicanismo ao catolicismo romano (N. T.). 
mica do clero paroquial elizabetano inicial (BROOKS, 1948; BARRETT, 1949; HOSKINS, 1950; TYLER, 1957). Do lado da Igreja Estabelecida ${ }^{27}$ estamos começando a ter um quadro mais adequado do crescimento do puritanismo por meio de um conhecimento maior sobre quem os puritanos eram, embora muito trabalho ainda permaneça para ser feito sobre os mercadores, cavalheiros, mestres-escola, clero e nobres puritanos $^{28}$. Do outro lado, uma comparação muito cuidadosa em termos estatísticos e geográficos entre os católicos dos anos 1560 e os da década de 1580 provou conclusivamente, como nenhum outro método poderia fazer, que o desenvolvimento do catolicismo do período elizabetano final era uma revivescência baseada na pequena nobreza, estimulada pelas atividades missionárias de sacerdotes seminaristas e não uma sobrevivência do catolicismo popular anterior à Reforma (DICKENS, 1941; cf. também MAGEE, 1938; BOSSY, 1962).

A história social, que se preocupa mais com grupos que com indivíduos, idéias ou instituições, é um campo para o qual a prosopografia tem mais a contribuir. Tentativas de generalizar sobre a mudança social antes ou de estudos locais detalhados ou de estatísticas globais baseadas em sérias pesquisas arquivísticas levaram ao tipo de impasse em que a famosa "controvérsia da pequena nobreza" ["gentry controversy"] ficou presa 20 anos atrás, durante a qual hipóteses rivais sobre amplos movimentos sociais, entre 1540 e 1640, e suas relações com a revolução foram tratadas com desleixo com base em exemplos astuciosamente selecionados cuja tipicidade era totalmente desconhecida. Desde aquela época apareceram vários estudos locais de grupos da pequena nobreza e um estudo geral sobre a aristocracia, que em conjunto deram alguns passos para eliminar certas hipóteses e conferir peso estatístico a outras ${ }^{29}$.

27 A expressão "Igreja Estabelecida" (em inglês: "Established Church") é uma designação geral para as religiões oficiais de Estado (N. T.).

${ }^{28}$ Há uma boa dose de material prosopográfico incidental no grande livro de Collinson (1967), The Elizabethan Puritan Movement; cf. também Seaver (1970, cap. 5-6).

29 Para um resumo da controvérsia, cf. Finch (1956), Stone (1965a, p. xi-xxvi; 1965b), Lloyd (1968) e Cliffe (1969). Nos últimos anos algo como 20 teses de doutorado foram ou estão sendo escritas sobre grupos da pequena nobreza de vários condados.
Por exemplo, como um resultado de muitos anos de trabalho muito cuidadoso sobre a pequena nobreza de Yorkshire, demonstrou-se que, da pequena nobreza do interior que estava em declínio econômico antes da guerra e que tomou partido, três quartos juntaram-se aos realistas e somente um quarto aos parlamentaristas (CLIFFE, 1969, p. 354$)^{30}$. Se isso é verdade para todo o país, isso refuta a hipótese do Professor Trevor-Roper de que os radicais do lado parlamentarista representava o declínio da "mere gentry". A mesma pesquisa também mostra a importância do puritanismo entre tantos parlamentaristas e do catolicismo entre um número significativo de realistas. Ela põe um prego a mais no caixão da antiga teoria marxista, apoiada em caráter tentativo por R. H. Tawney e J. E. C. Hill, de que a Guerra Civil foi um conflito entre os empresários capitalistas senhoriais e os rentistas à moda antiga. Nesse caso, a análise prosopográfica detalhada pôs sob teste como nenhuma outra poderia - as várias teorias das causas sociais da revolução e começou a separar nelas a verdade do erro ${ }^{31}$.

Como se poderia esperar, a maior concentração de energia prosopográfica foi dirigida à elite política e em particular aos membros do parlamento. Os historiadores do final do século XIX e do início do século XX determinaram o papelchave desempenhado na história política inglesa pela crescentemente independente e poderosa Câmara dos Comuns e sabe-se há tempo que era ali que os temas básicos eram discutidos. Mas não foi senão após a II Guerra Mundial que os pesquisadores começaram a questionar-se a respeito de qual tipo de pessoa fazia essa história. Hoje temos estudos dos membros do parlamento de quase toda legislatura entre 1559 e 1660 e um quadro muito mais rico e convincente emergiu disso como resultado ${ }^{32}$. Por meio da comparação estatística e de uma série de detalhados estudos

30 Esses percentuais e as conclusões tiradas a partir deles são minhas, não do Dr. Cliffe.

31 A prosopografia também minou uma outra hipótese sobre as causas da Guerra Civil, nomeadamente as afirmações de H. R. Trevor-Roper a respeito do papel da burocracia (cf. AYLMER, 1959).

32 Teses não publicadas dos pupilos de Sir John Neale e brilhantes síntese e interpretação desses achados podem ser encontrados em seu Elizabethan House of Commons (NEALE, 1949). Cf. também Brunton \& Pennington (1954), Keeler (1954), Moir (1958), Pinkney (1962) e Helms (1963). 
de caso, podemos observar a expansão nos números de membros do parlamento e atribuir sua causa a um desejo dos magnatas elizabetanos de ampliar o escopo de sua patronagem e à disposição de Elizabeth de fazer concessões que, embora politicamente imprudentes no longo prazo, não lhe custaram seu dinheiro no curto prazo. Investigações estatísticas revelaram o impressionante crescimento da escolarização e da experiência administrativa dos membros do parlamento e o persistente crescimento na proporção da pequena nobreza. Sabemos agora como os membros foram eleitos e como as disputas eleitorais foram travadas e vencidas e estamos agora começando a aprender um pouco a respeito da relação cambiante entre os eleitores e seus representantes. Podemos traçar o declínio de influência eleitoral das grandes cortes de magnatas antes de 1640, ao mesmo tempo em que elas cederam espaço para as dos cavalheiros locais e mesmo dos próprios citadinos por assentos dos distritos urbanos [borough seats ${ }^{33}$.

Os estudos prosopográficos das elites locais externas ao parlamento, nos condados e nas cidades, estão apenas começando a ser mais úteis em iluminar os fatores econômicos e sociais por trás das fileiras partidárias na Guerra Civil. Eles já revelaram que em alguns condados e cidades - mas não em todos - houve uma perda de posições da autoridade no final dos anos 1640 de membros de pequena nobreza mais ampla, originária das antigas oligarquias urbanas, e sua substituição por homens originários de uma pequena nobreza mais restrita e por pequenos mercadores, à medida que políticas públicas mais radicais foram adotadas para a continuação da guerra e para a obtenção de um acordo político (PEARL, 1961, p. 160; EVERITT, 1966, p. 143; HOWELL, 1967, p. 171173; para a velha elite que permanecia em Suffolk, cf. EVERITT, 1960).

A principal conclusão que emerge dessa pesquisa bibliográfica é que o método funciona melhor quando é aplicado para grupos facilmente definidos e razoavelmente pequenos, em um período limitado de não muito mais que 100 anos, quando os dados são obtidos de uma grande variedade de fontes que complementam e enriquecem umas às outras e quando a pesquisa é dirigida para

33 Um borough é uma cidade na Inglaterra que consiste, também, em um distrito eleitoral (N. T.). solucionar um problema específico. Lolardos e protestantes no início do século XVI, revoltosos do Capitão Swing ${ }^{34}$ no início do século XIX compõem objetos ideais. Pesquisas ambiciosas sobre muitas centenas de indivíduos, durante períodos temporais muito amplos, usando apenas as fontes materiais escritas mais facilmente acessíveis e aplicando uma abordagem no estilo "metralhadora giratória" aos problemas que podem ser formulados são muito menos prováveis de produzir resultados convincentes.

\section{CONCLUSÃO}

A prosopografia está hoje no processo de amadurecimento. Ela passou pelas loucuras e pelos excessos da adolescência e está agora sossegando na rotina monótona de um responsável começo de meia-idade. Se a escola elitista teve seus inícios na Alemanha e nos Estados Unidos, ela desenvolveu-se primeiramente na Inglaterra, tanto na história clássica quanto na moderna, e uma boa dose do seu trabalho ainda vem de lá. Mas esse pioneirismo inicial agora está sendo ultrapassado, tanto em quantidade quanto em qualidade, pelas expansões acadêmicas dos Estados Unidos. Os últimos sempre foram o principal centro da escola de massas, cujas escala de seus resultados e sofisticação de seus métodos estão agora crescendo com rapidez ${ }^{35}$. As principais causas dessa proliferação da prosopografia histórico-científica nos Estados Unidos são a grande influência da Sociologia e da Ciência Política e o avançado treinamento no uso de - e o fácil acesso a - computadores. A mais impressionante realização institucional dessa escola foi a criação do InterUniversity Consortium for Political Research ${ }^{36}$ na Universidade de Michigan. Aí estão sendo coletadas e postas em forma legível pelos com-

34 Os revoltosos do Capitão Swing (Captain Swing, no original em inglês) eram camponeses ingleses que se revoltavam contra a modernização do campo no início do século XIX. Para ameaçar seus senhorios, escreviam cartas anônimas que eram assinadas por "Swing" ou "Captain Swing" (N. T.).

35 Algumas investigações notáveis de elites, feitas por pesquisadores estadunidenses sobre a história dos Estados Unidos, são as de Bailyn (1955), Mills (1956), Aronson (1964), Rothman (1966), Main (1967) e Harris (1969). Para bibliografias sobre a escola de massas, cf. a nota 7 , acima.

36 Consórcio Interuniversitário para a Pesquisa Política, no original em inglês (N. T.). 
putadores informações sobre o comportamento eleitoral de cada congressista desde 1789 , conforme registrado nas listas de chamada do Congresso dos Estados Unidos. Some-se a isso que os psefologistas estão recebendo dados sobre a votação popular no nível dos condados em cada eleição desde 1824, correlacionados com informações dos censos desde 1790 sobre renda, raça, religião e outras variáveis-chave para cada condado e estado (cf. CLUBB, 1969). Começou-se agora a coletar-se informações estatísticas legíveis pelos computadores sobre períodos anteriores da história estadunidense e também de outros países.

É indicativo da divisão de caminhos entre as academias britânica e estadunidense nos anos 1960 que o monumento paralelo à prosopografia no lado oriental do Oceano Atlântico assume a forma um tanto diferente do projeto "História do parlamento no pós-guerra". Iniciado e planejado por Sir Lewis Namier, ele começou em 1951 e resultará em um dicionário biográfico em vários volumes que usará essas informações pessoais para apoiar estudos de caso esclarecedores, juntar comparações estatísticas e elaborar conclusões políticas. É característico da abordagem britânica que esse projeto seja pago pelo Estado e não por universidades ou fundações, que as informações biográficas que ele reúne não esteja sendo preparado para o formato legível por computador (exceto as de um período, sob a responsabilidade de um estadunidense) e que se esteja dando maior ênfase às biografias e aos estudos de caso que às estatísticas $^{37}$.

A França é o terceiro maior centro de pesquisa histórica no mundo, mas nos últimos 30 anos os melhores historiadores franceses estiveram preocupados com algumas explorações deslumbran-

\footnotetext{
37 A primeira tentativa abortada para lançar esse projeto ocorreu em 1929, quando um comitê oficial foi criado pela Câmara dos Comuns para investigar "os materiais disponíveis para um registro do pessoal e da política dos membros passados da Câmara dos Comuns de 1264 a 1832 e o custo dessa publicação". O comitê deu um parecer favorável e nos anos 1930 o Coronel Wedgwood produziu dois volumes sobre os membros do parlamento entre 1439 e 1509 . Infelizmente, ele fracassou em publicar o terceiro volume de síntese e, de qualquer maneira, os seus métodos foram tão criticados que qualquer trabalho posterior seguindo suas linhas foi abandonado (WEDGWOOD, 1936-1938; MCKISACK, 1938).
}

temente bem-sucedidas de outras novas técnicas de pesquisa. Eles avançaram em alguns brilhantes estudos ambientais sobre sociedades locais vistas como totalidades e examinadas com grande profundidade; eles produziram algumas maciças séries estatísticas temporais sobre preços, comércio exterior e produtos industriais e têm sido os pioneiros no estudo científico da demografia histórica. Somente nos últimos anos os historiadores franceses começaram a usar a prosopografia e, em conformidade com sua ênfase de longa data na quantificação, eles agora se envolveram em alguns projetos de enorme escala da escola de massas, usando o mais sofisticado maquinário computacional (LEROY LADURIE, BERNAGEAU \& PASQUET, 1969; recentes pesquisas francesas sobre as elites incluem: BLUCHE, 1960; CORVISIER, 1964; GIRARD, PROST \& GOSSEZ, 1967). Essas pesquisas estão sendo apoiadas pela VI Seção da École Pratique des Hautes Études, de Paris, que desde há décadas é o centro de pesquisas estatísticas históricas da França.

Uma das razões - embora uma pobre e irrelevante - por que a prosopografia continuará a desenvolver-se em ambos os lados do Atlântico é o fato de ela ser tão idealmente adequada aos requisitos de artigos de pesquisa e de teses de doutorado. Ela apresenta ao estudante novato uma grande variedade de fontes, ensina-lhe a avaliar as evidências e a aplicar seu julgamento para resolver contradições, demanda acurácia meticulosa, a organização das informações de maneira metódica e oferece um tópico que pode ser facilmente expandido ou reduzido pela modificação do tamanho da amostra de modo a adequar-se aos requerimentos dos recursos e dos prazos disponíveis. Algo dessa pesquisa sem dúvida contribui para um neo-antiquarianismo - recolhimento dos dados apenas pelo próprio recolhimento de dados mas sob uma liderança habilidosa e organizada os projetos podem ser agrupados pelo diretor a fim de produzir uma contribuição útil para o aumento do conhecimento histórico.

Uma segunda poderosa razão - mas igualmente irrelevante - para a expansão subseqüente da prosopografia é a chegada do computador, cujo significado completo está apenas começando a tornar-se aparente. Como os historiadores lenta e timidamente começam a explorar as potencialidades da nova ferramenta tecnológica, eles começam a perceber sua quase ilimitada capacidade de lidar precisamente com o tipo de 
material que a prosopografia apura. A correlação de numerosas variáveis afetando grandes massas de dados, reunidas em uma base uniforme, é precisamente o que o computador pode fazer melhor; é também o que há de mais laborioso e, em vários casos, virtualmente impossível de trabalhar sem auxílios eletrônicos, mesmo para os historiadores com orientação mais matemática,. É doloroso admitir que o advento de um aparato técnico poderia ditar o tipo de questões históricas formuladas e os métodos utilizados para solucionálos, mas seria adotar a postura do avestruz fingir que isso não está acontecendo agora e que não acontecerá em uma escala ainda maior nos anos vindouros.

Deve-se admitir que há alguns sérios perigos inerentes ao sucesso e popularidade da prosopografia. O primeiro é que as realizações realmente grandes - como o trabalho de Sir John Neale sobre os parlamentos elizabetanos, o do Professor W. K. Jordan sobre as doações caritativas ou o projeto ainda maior sobre a história do parlamento, de Sir Lewis Namier - devem ser levadas a cabo por equipes de pesquisadores, reunindo dados nos termos estabelecidos pelo diretor. Esse material então é estudado, coletado e finalmente publicado pelo diretor, para quem sozinho vai o crédito (cf. NEALE, 1958, p. 229-234). A pesquisa coletiva já é aceita totalmente pelos cientistas naturais como um processo familiar e necessário, mas ele envolve um grau de patronagem $^{38}$ do pesquisador-chefe sobre estudantes e pesquisadores iniciantes que muitos pesquisadores criados na antiga tradição historiográfica individualista e independente consideram perturbador. $\mathrm{O}$ segundo perigo é que, em vez de andarem juntas, as escolas de massas e elitista especializar-se-ão mais e mais em suas diferentes abordagens, a primeira tornando-se mais científica e quantitativa e a outra mais impressionista e devotada aos exemplos individuais inadequadamente controlados pela amostragem aleatória. Isso seria um desastre para a profissão, pois significaria o fim de frutíferas fertilizações cruzadas. O perigo foi bastante aumentado pelo advento do computador, que foi adotado pelos

38 No original, o autor usou "peonage", que literalmente significa “condição de peão". Como não há um termo sintético equivalente em português, preferimos "patronagem", que também sugere uma relação de subordinação intelectual e laboral (N. T.). pesquisadores mais estatisticamente orientados com todo o entusiasmo indiscriminado dos ninfomaníacos e rejeitado pelos menos científicos, em parte devido a melindres intelectuais, em parte devido a uma complacência ignorante dos prazeres que estão perdendo. A disponibilidade do computador crescentemente seduzirá os historiadores a concentrar suas energias nos problemas que podem ser solucionados pela quantificação, problemas que às vezes - mas de maneira nenhuma sempre - são os mais importantes ou interessantes. Ela também os seduzirá a abandonar as técnicas de amostragem, que com freqüência são perfeitamente adequadas para seus propósitos, e a embarcar em investigações estatísticas que consomem grande tempo sobre populações totais, que em muitos casos são procedimentos completamente desnecessários. Outros historiadores podem crescentemente vir a perceber o computador como uma ameaça ao seu predomínio intelectual e retirarem-se ainda mais nos recessos negros da metodologia impressionista. Para piorar as coisas, há fortes traços nacionais para essa divisão de perspectivas - pois os estadunidenses e os franceses têm muito mais acesso a e confiança nos computadores que seus colegas ingleses -, fortes traços culturais - com ameaças de uma nova guerra entre os antigos e os modernos, entre as humanidades e as ciências - e mesmo traços filosóficos - com um choque entre o fato e a imaginação, Mr. Gradgrind e Sissy Jupe ${ }^{39}$. Como resultado, pode demorar bastante até que haja uma completa reunião de perspectivas.

A prosopografia, no entanto, contém em seu interior a potencialidade para ajudar na recriação de um campo unificado além da frágil confederação de tópicos e técnicas zelosamente independentes que no presente constitui o império dos historiadores. Ela pode ser um meio para vincular a história constitucional e institucional, por um lado, à história biográfica, por outro lado, que são as duas mais antigas e melhor desenvolvidas do ofício de historiador, mas que até agora seguiram linhas mais ou menos paralelas. Ela combinaria a habilidade humana na reconstrução histórica por meio da concentração meticulosa nos detalhes sig-

39 Mr. Gradgrind e Sissy Jupe são personagens do livro Hard Times, de Charles Dickens. Deixando de lado os caracteres literários desses personagens, as referências a eles indicam respectivamente a preocupação fria com os fatos, por um lado, e a imaginação e a esperança, por outro (N. T.). 
nificativos e nos exemplos particulares com as preocupações estatísticas e teóricas; formaria o elo perdido entre a história política e a história social, que no presente são todas freqüentemente tratadas em compartimentos amplamente impermeáveis, mesmo em diferentes monografias ou em diferentes capítulos de um mesmo volume. Ela ajudaria a reconciliar a História com a Socio- logia e a Psicologia. E formaria um fio entre outros para ancorar os excitantes desenvolvimentos da História Intelectual e Cultural na sua fundação social, econômica e política. Se a prosopografia realizará ou não todas ou algumas dessas oportunidades dependerá do conhecimento técnico, da sofisticação, da modéstia e do bom senso da nova geração de historiadores.

Lawrence Stone (1919-1999) foi historiador e professor na Universidade de Oxford (Inglaterra) e na Universidade de Princeton (Estados Unidos).

\section{REFERÊNCIAS BIBLIOGRÁFICAS}

AGNEW, D. C. A. 1886. Protestant Exiles from France in the Reign of Louis XIV. Edinburgh: Huguenot Society.

ANNAN, N. 1955. The Intellectual Aristocracy. In: PLUMB, J. H. (ed.). Studies in Social History. London: Longmans, Green.

ARONSON, S. H. 1964. Status and Kinship in the Higher Civil Service. Cambridge, Mass.: Harvard University.

ASTON, M. 1964. Lollardy and the Reformation: Survival or Revival? History, Malden, v. 49, n. 166 , p. $149-170$.

AYDELOTTE, W. O. 1967. The Country Gentlemen and the Repeal of the Corn Laws. English Historical Review, Oxford, v. 82, n. 322, p. 47-60, Jan.

1969. Voting Patterns in the British House of Commons in the 1840's. In: ROWNEY, D. K. \& GRAHAM, J. Q. Quantitative History. Homewood: Dorsey.

AYLMER, G. E. 1959. Office-Holding as a Factor in English History, 1625-42. History, Malden, v. 44, n. 152, 228-240, Oct.

1961. The King's Servants: The Civil Service of Charles I, 1625-1642. London: Routledge and Paul.

BADIAN, E. 1958. Foreign Clientelae. Oxford: Oxford University.

BAILYN, B. 1955. New England Merchants in the Seventeenth Century. Cambridge, Mass.: Harvard University.

BARRETT, D. M. 1949. The Condition of the Parish Clergy Between the Reformation and
1660. Ph.D. Thesis. Oxford University.

BASKERVILLE, G. 1937. English Monks and the Suppression of the Monasteries. London: Cape.

BEARD, C. A. 1913. An Economic Interpretation of the Constitution of the United States. New York: Macmillan.

1935. An Economic Interpretation of the Constitution of the United States. $2^{\text {nd }}$ ed. New York: Macmillan.

BEAVEN, A. B. 1908-1913. Aldermen of the City of London. London: $\mathrm{s} / \mathrm{n}$.

BLUCHE, F. 1960. Les Magistrats du Parlement de Paris au XVIIIe siècle. Paris: Les Belles Lettres.

BOSSY, J. 1962. The Character of Elizabethan Catholicism. Past and Present, Oxford, v. 21, n. 1 , p. 39-59.

BOWKER, M. 1968. The Secular Clergy in the Diocese of Lincoln - 1495-1520. Cambridge, UK: Cambridge University.

BROOKS, F. W. 1948. The Social Position of the Parson in the Sixteenth Century. British Archaeological Society Journal, $3^{\text {rd }}$ series, v. 10.

BRUNT, P. A. 1968. Review of Meier's Res Publica Amissa. Journal of Roman Studies, v. 58, p. 229-232.

BRUNTON, D. \& PENNINGTON, D. H. 1954. Members of the Long Parliament. London: Allen and Unwin.

BURKE, J. 1833-1838. The Commoners of Great Britain and Ireland. London: $\mathrm{s} / \mathrm{n}$. 
BUTTERFIELD, H. 1957. George III and the Historians. London: Collins.

CAMPBELL, J. 1742-1744. Lives of the Admirals. London: s/n.

1845-1847. Lives of the Lord Chancellors. London: s/n. $\mathrm{s} / \mathrm{n}$

1849. Lives of the Chief Justices. London:

CHARNOCK, J. 1794-1798. Biographia Navalis. London: $\mathrm{s} / \mathrm{n}$.

CLEBSCH, W. 1964. England's Earliest Protestants - 1520-1535. New Haven: Yale University.

CLIFFE, J. T. 1969. The Yorkshire Gentry. London: Athlone.

CLUBB， M. 1969. The Inter-University Consortium for Political Research: Progress and Prospects. Historical Methods Newsletter, v. 2, June.

COLEMAN, D. C. 1966. The 'Gentry' Controversy and the Aristocracy in Crisis, 1558-1641. History, Malden, v. 50, n. 172, p. 165, 178, June.

COLLINS, A. 1714. The Peerage of England. London: $\mathrm{s} / \mathrm{n}$.

1720. The Baronetage of England. London: $\mathrm{s} / \mathrm{n}$.

COLLINSON, P. 1967. The Elizabethan Puritan Movement. London: Cape.

CORVISIER, A. 1964. L'Armée française de la fin du XVIIe siècle au ministère de Choiseul. Paris: PUF.

DALTON, C. 1892-1904. English Army Lists 1661-1714. London: s/n.

1910. George the First's Army - 17161727. London: s/n.

DARLINGTON, C. D. 1969. The Genetics of Society: History and Genetics. Past and Present, Oxford, v. 43, n. 1, p. 3-33.

DAVIS, J. F. 1966. Lollard Survival and the Textile Industry in the South-East of England. Studies in Church History, Rochester, v. 3, p. 191-201.

DICKENS, A. G. 1941. The First Stages of Romanist Recusancy in Yorkshire, 1560-1590. Yorkshire Archaeological Journal, v. 35.
1959. Lollards and Protestants in the Diocese of York. London: Oxford University.

DONALD, D. 1956. Towards a Reconsideration of Abolitionists. In: Lincoln Reconsidered. New York: Knopf.

EDINGER, L. J. \& SEARING, D. S. 1967. Social Background in Elite Analysis: A Methodological Enquiry. American Political Science Review, Washington, D. C., v. 61, n. 2, p. 428-445, June.

EVERITT, A. 1960. Suffolk and the Great Rebellion, 1640-1660. Suffolk Record Society, v. 3.

1966. The Community of Kent and he Great Rebellion - 1640-1660. Leicester: Leicester University.

FINCH, M. E. 1956. The Wealth of Five Northamptonshire Families - 1540-1640. Oxford: Northamptonshire Record Society.

FOSS, E. 1870. Biographia Juridica. A Biographical Dictionary of the Judges of England... 1066-1870. London: s/n.

FOSTER, J. 1891-1892. Alumni Oxonienses. Oxford: $\mathrm{s} / \mathrm{n}$.

GARRETT, C. H. 1938. The Marian Exiles. Cambridge, Eng.: Cambridge University.

GEIZER, M. 1912. Die Nobilität der römischen Republik. Leipzig-Berlin: B. G. Teubner.

GILLOW，J. 1885-1902. Bibliographical Dictionary of English Catholics - 1534-1902. $\mathrm{S} / \mathrm{l}: \mathrm{s} / \mathrm{n}$.

GIRARD, L.; PROST, A. \& GOSSEZ, R. 1967. Les Conseillers Généraux en 1870. Paris: PUF.

GREER, D. 1964. The Incidence of the Terror During the French Revolution: A Statistical Interpretation. $3^{\text {rd }}$ ed. Cambridge, Mass.: Harvard University.

GUTTSMAN, W. L. 1963. The British Political Elite. London: MacGibbon and Kee.

HARRIS, P. M. G. 1969. The Social Origins of American Leaders: The Demographic Foundations. Perspectives in American History, v. 3, p. 159-364.

HEATH, P. 1969. The English Parish Clergy on the Eve of the Reformation. London: Routledge and Paul. 
HELMS, M. E. W. 1963. The Convention Parliament of 1660. Ph.D. Thesis. Bryn Mawr College.

HENNESSY, G. 1898. Repertorium Ecclesiasticum Parochiale Londinense. London: $\mathrm{s} / \mathrm{n}$.

HEXTER, J. H. 1941. The Reign of King Pym. Cambridge, Mass.: Harvard University.

1968. The English Aristocracy, Its Crises, and the English Revolution, 1558-1660. Journal of British Studies, Chicago, v. 8, n. 1, p. 22-78, Nov.

HOBSBAWM, E. J. \& RUDE, G. 1969. Captain Swing. London: Lawrence and Wishart.

HODGETT, G. A. J. 1962. The Unpensioned ExReligious in Tudor England. Journal of Ecclesiastical History, v. 13.

HOLMES, G. 1967. British Politics in the Age of Anne. London: Macmillan.

HOLT, C. 1961. The Northerners. Oxford: Oxford University.

HOOK, W. F. 1860-1876. Lives of the Archbishops of Canterbury. London: s/n.

HOSKINS, W. G. 1950. The Leicestershire Country Parson in the Sixteenth Century. In: Essays in Leicestershire History. Liverpool: Liverpool University.

1952. The Estates of the Caroline Gentry. In: HOSKINS, W. G. \& FINBERG, H. P. R. (eds.). Devonshire Studies. London: Cape.

HOWELL, R. G. 1967. Newcastle upon Tyne and the Puritan Revolution. Oxford: Clarendon.

KEELER, F. 1954. The Long Parliament - 16401641. Philadelphia: American Philosophical Society.

LASSWELL, H. D. \& LERNER, D. 1965. World Revolutionary Elites: Studies in Coercive Ideological Movements. Cambridge, Mass.: MIT.

LE ROY LADURIE, E.; BERNAGEAU, N. \& PASQUET, Y. 1969. Le conscrit et l'ordinateur: perspectives de recherches sur les archives militaires du XIXe siècle français. Studi Storici, Roma, anno 10, n. 2, p. 260-308, apr.-jun.

LLOYD, H. A. 1968. The Gentry of South-West Wales - 1540-1640. Cardiff: University of Wales.
MAGEE, B. 1938. The English Recusants. London: Burns, Oates and Washbourne.

MAIN, J. T. 1967. The Upper House in Revolutionary America - 1763-1788. Madison: University of Wisconsin.

MCCUSKER, J. J. 1969. Review. Historical Methods Newsletter, v. 2, p. 16-17, June.

MCFARLANE, K. B. 1945. Bastard Feudalism. Bulletin of the Institute for Historical Research, v. 20.

MCKISACK, M. 1938. Review of Wedgwood's History of Parliament. English Historical Review, v. 53, p. 503-506.

MEIER , C. 1966. Res Publica Amissa. Wiesbaden: Steiner.

MERTON, R. K. 1938. Science, Technology, and Puritanism in Seventeenth Century England. Osiris, Notre Dame (Illinois), v. 4, p. 360-632

MILLS, C. W. 1956. The Power Elite. New York: Oxford University.

MOIR, T. L. 1958. The Addled Parliament of 1614. Oxford: Clarendon.

MOMigLiANO, A. 1940. Review of Syme's The Roman Revolution. Journal of Roman Studies, v. 30, p. 5 .

MUNK, W. 1861. Roll of the Royal College of Physicians of London. S/l: s/n.

MUNZER, F. 1920. Römische Adelsparteien und Adelsfamilien. Stuttgart: s/n.

NAMIER, B. 1929. Structure of Politics at the Accession of George III. London: MacMillan.

1961. England in the Age of the American Revolution. $2^{\text {nd }}$ ed. London: Macmillan.

NAMIER, L. B. \& BROOKE, J. 1964. The House of Commons - 1754-1790. London: Oxford University.

NEALE, J. E. 1949. The Elizabethan House of Commons. London: Cape.

1953. Elizabeth I and Her Parliaments 1559-1581. London: Cape.

1958. The Biographical Approach to History. In:__. Essays in Elizabethan History. New-York: St. Martin's. 
NEWTON, A. P. 1914. The Colonising Activities of the English Puritans. New Haven: Yale University.

NICOLET, C. 1970. Prosopographie et histoire sociale: Rome et Italie à l'époque républicaine. Annales: économie, sociétés, civilisations, $\mathrm{Pa}-$ ris, v. 25, n. 5, p. 1209-1228. Disponível em: http://www.persee.fr/web/revues/home/ prescript/article/ahess_03952649_1970_num_25_5_422266. Acesso em : 1.abr.2011.

PEARL, V. 1961. London and the Outbreak of the Puritan Revolution. London: Oxford University.

PETERSEN, E. L. 1968. The Elizabethan Aristocracy Anatomized, Atomized and Reassessed. Scandinavian Economic History Review, v. 16.

PINKNEY, P. J. 1962. The Cromwellian Parliament of 1656. Ph.D. Thesis. Vanderbilt University.

PLUMB, J. H. 1967. The Origins of Political Stability: England, 1675-1725. Boston: Houghton Mifflin.

POTTINGER, D. 1958. The French Book Trade in the Ancien Regime - 1500-1791. Cambridge, Mass.: Harvard University.

RABB, T. K. 1967. Enterprise and Empire: Merchant and Gentry Investment in the Expansion of England - 1575-1630. Cambridge, Mass.: Harvard University.

RAYMOND, J. 1957. New Statesman. October 19, 1957, p. 499-500.

ROTHMAN, D. J. 1966. Politics and Power: The United States Senate-1869-1901. Cambridge, Mass.: Harvard University.

ROWNEY, D. K. \& GRAHAM, J. Q. 1969. Quantitative History. Homewood: Dorsey.

RUSTOW, D. A. 1966. The Study of Elites: Who's Who, When, and How. World Politics, Cambridge, v. 18, n. 4, p. 690-717, July.

SEAVER, P. S. 1970. The Puritan Lectureships. Stanford: Stanford University.

SKOTHEIM, R. A. 1959. A Note on Historical Method: David Donald's Towards a Reconsideration of Abolitionists. Journal of Southern History, Athens, Georgia, v. 25, n. 3,

\section{p. 356-365, Aug.}

SMITH, L. B. 1953. Tudor Prelates and Politics. Princeton: Princeton University.

STONE, L. 1965a. Social Change and Revolution in England - 1540-1640. London: Longmans.

1965b. The Crisis of the Aristocracy: 15581641. Oxford: Oxford University.

SYME, R. 1939. The Roman Revolution. Oxford: Oxford University.

TAYLOR, L. R. 1949. Party Politics in the Age of Caesar. Berkeley: University of California.

TIRAT, J.-Y. 1963. Problèmes de méthode en histoire sociale. Revue d'Histoire Moderne et Contemporaine, Paris, t. 10, n. 3, p. 211-218, juil.-sept.

TREVOR-ROPER, H. R. 1953. The Gentry, 1540-1640. Economic History Review, Supplement I.

. 1967. Oliver Cromwell and His Parliament. In:__. Religion, the Reformation and Social Change. London: Macmillan.

TYLER, P. 1957. The Status of the Elizabethan Parochial Clergy. Studies in Church History, v. 4.

VENN, J. \& VENN, J. A. 1922-1954. Alumni Cantabrigienses. Cambridge, UK: s/n.

WALCOTT, R. 1956. English Politics in the Early Eighteenth Century. Oxford: Oxford University.

WALZER, M. 1965. The Revolution of the Saints. Cambridge, Mass.: Harvard University.

WEDGWOOD, J. C. 1936-1938. History of Parliament. Biographies of Members of the Commons' House, 1439-1509. London: His Majesty's Stationery Office.

WILSON, J. 1806. Biographical Index to the Present House of Commons. London: $\mathrm{s} / \mathrm{n}$.

WINSTANLEY, D. A. 1929. Reviewing Namier. Historical Review, v. 44, p. 660.

WOOLF ，S. J. 1969. La transformazione dell'aristocrazia et la Revoluzione Inglese. Studi Storici, Roma, anno 10, n. 2, p. 309-334, apr.jun.

WOOLRYCH, H. W. 1869. Lives of Eminent Sergeants-at-Law. London: s/n. 